VOL. XI, NO. 10.-BOTANICAL GAZETTE.-OCT., 1886.

\title{
Memoranda of a revision of the North American Violets. ${ }^{1}$ I.
}

\author{
ASA GRAY.
}

It seems most natural to throw all the Candollian groups into one, except the section Melanium, which includes the pansies; in this, following the late M. Boissier; and to arrange our violets in six primary sections, upon characters of vegetation taken along with differences in the stigma.

Group I. Strictly acaulescent; the dissected leaves and scapes all directly from an erect and short thick caudex rather than rootstock, never stoloniferous : corolla beardless: large antrorse-terminal stigma wholly beakless and naked.

V. pedata L., with var. bicolor Pursh, fide Raf.

Group II. Acaulescent; the leaves and scapes springing directly from the summit of a rootstock, or later more or less from runners: style with inflexed or truncate and beardless summit and an antrorsely beaked or short pointed small stigma.

* Rootstocks thick and short, multicipital, ascending or little creeping, never filiform nor stoloniferous, often fleshy-dentate: corolla only saccatespurred, blue or violet, occasionally varying to white; at least lateral petals bearded. Species connected by transitions.

V. pedatifida Don. Syst. i. 320 (1831). V. delphinifolia Nutt. in Torr. \& Gray, Fl. i. 136 (1838). This earlier name clearly belongs here and must be adopted. It is the $V$. pinnata of Richardson (not the Linnæan species, which has longer and narrower spurs), the $V$. pedata of Hooker's Flora as to the plant of Saskatchewan, etc. It has often been confounded with that species; but its affinities are with V. palmata, indeed is probably only a marked geographical variety of that species, with all the leaves finely dissected. It might take the much earlier name of $V$. digitata Pursh, except that Pursh founded it on a Virginian specimen, which he had seen in Major Le Conte's herbarium. The latter, however, makes no mention of it in his monograph; but we suppose it to be his $V$. septemloba, the variety of $V$. palmata which comes nearest to the present species. Indeed, the late Professor Tuckerman long ago collected at Concord, Massachusetts, specimens which would surely pass for $V$. pedatifida if from the valley of the Mississippi.

1Read before the A. A. A. S., Buffalo meeting, 1886. 
V. palmata $\mathrm{L}$. In the year 1856 , in the second edition of my Manual, this was combined with $V$. cucullata, following the general conviction of our botanists; repeated studies during thirty years confirm the opinion. But V.cucullata Ait. ought to have been referred, as an entire-leaved variety, to the Linnæan V. palmata. I am the more constrained to do so now by the fact that the name cucullata would have to give way to the much earlier-published $V$. obliqua Hill, well figured and unmistakable in his Hortus Kewensis. To the various synonyms already adduced to the more or less cut-leaved forms of this multifarious and widely diffused species, I have only to add that of $V$. digitata Pursh, as suggested above.

Var. cucullata, the V. cucullata of Aiton (1789) and V.obliqua Hill (1769), with abundant synonymy, is characterized only negatively by the absence of cut leaves, and every one of its many forms is liable to have them, most so those which affect dry or sandy soil. Yet they have not been found at either the most northern or the farthest western limits of the species.

V. sagittata Ait. Generally well-marked as this is, yet it appears to be confluent on one hand into typical $V$. palmata, on the other into the var. cucullata.

* * Rootstocks thickish and creeping, stoloniferous, comparatively large-flowered : corolla blue or violet, with white varieties; lateral petals usually bearded; spur short and saccate: leaves cordate and merely crenulate.

V. Langsdorffii Fischer in DC. Arctic Alaska to Brit. Columbia, extending, I believe, to the Sierra Nevada in the state of Nevada. Quite distinct, as Maximowicz insists, from the more caulescent $V$.mirabilis.

V. odorata L., the Sweet Violet of the Old World, beginning to be naturalized.

*** Rootstocks long and filiform (not thickened nor scaly except at base of old flowering growths), extensively creeping underground, sometimes in summer along the surface in shade, leaf-mould, etc.

+ Corolla blue or purple, large-spurred, beardless.

V. Selkirkii Pursh, fide Goldie. Our identification of this northern species with $V$. Kamtschatica of Gingius in DC., and with $V$. umbrosa of Fries, appears to be confirmed. Few botanists are aware that John Goldie, the first describer of this marked species, and of several other Canadian plants, lived down to the present summer, dying at a great age, at Ayr, Ontario, June 1886.*

+ + Corolla blue or purple, short-spurred, smaller.

* See sketch of Goldie's life, p. 272, this number. 
V. palustris L. In this country only alpine or subalpine, Labrador to Saskatchewan and Rocky Mountains, south to those of Colorado, and the higher parts of those of New England.

$+\quad+$ Corolla white, mostly with brown-purple lines on lower or also on lateral petals or a blotch, these bearded or beardless in the same species; spur short and saccate : stigma as if truncate and margined, antrorsely short-pointed. The three species run together.

V. blanda Willd. Geographical range fully as large as that of $V$. palmata. To this I refer two forms, which in their extremes would seem specifically distinct, viz.:

Var. palustriformis. Comparatively large, growing in shady or mossy and loose soil or leaf-mould, where it is freely and extensively stoloniferous: upper face of the leaves commonly hirsutulous in the way of $V$. Selkirkii, but less so: scapes often reddish : flowers rather larger; lower petal less lineate or picturate. This is V. obliqua.Pursh (not Hill nor Ait.), and may also be his $V$. clandestina (in the summer state it is abundantly cleistogamous, and is the $V$. amoena of Le Conte). It ranges from Canada to Delaware, and to the mountains of Utah, but passes freely into the ordinary type. In the dried specimens it so much resembles $V$. palustris that Sir Joseph Hooker not unnaturally referred the whole of $V$. blanda to that species.

Var. renifolia. V. renifolia Gray, Proc. Am. Acad. viii. 288, which seems quite different from the ordinary state of $V$. blanda by its round reniform and beneath soft-pubescent leaves, is so connected with the preceding variety that it can not be kept distinct. It also grows in wet mossy woods and swamps, from Nova Scotia to the district north of Lake Superior, and south to Massachusetts and central New York.

V. primulifolia L., including $V$. acuta Bigelow, in its various forms, as is well known, fills up the interval between $V$. blanda and V. lanceolata. It is an Atlantic coast species, except as to

Var. occidentalis. A form with ovate- or spatulate-oblong leaves, all tapering at base, coll. by T. Howell, much out of the ordinary range, at Waldo, S. Oregon, along streamlets.

V. lanceolata $L$. has a rather larger range, from Nova Scotia to Lake Superior, Florida, and Texas.

+++ + Corolla yellow; lateral petals usually bearded.

V. rotundifolia Michx. Our only truly acaulescent yellow violet, well marked in its summer state by the unusually accrescent leaves lying flat on the ground. From the character and 
habitat this should be, in its cleistogamous-flowering summer state, the $V$. clandestina of Pursh.

GROUP III. Subcaulescent by leafy stolons, or caulescent, with ascending 2-3-leaved stems, slender, almost glabrous, multiplying by long filiform rootstocks: leaves all reniform or cordate, undivided: corolla a bright yellow, with saccate spur: stigma terminal, beardless and beakless.

V. sarmentosa Dougl. To this belongs V.rotundifolia Hook. in Lond. Jour. Bot. vi. 73, in Geyer's collection, a species which it considerably resembles at first, flowering direct from the rootstock.

V. biflora L. Always caulescent, no leafy stolons; stigma margined on two sides. In this country known only from the Colorado Rocky Mountains; in the Old World ranges from Kamtschatka and Japan to Europe.

\section{Synopsis of North American Pines, based upon leaf-anatomy.}

JOHN M. COULTER AND J. N. ROSE.

(WITH PLATE VIII. ${ }^{2}$ )

The genus Pinus is very naturally circumscribed, but its species have always been notably difficult of discrimination. This has arisen partly from the real difficulty of the subject, partly from the imperfect material found in our collections, and mostly from the insufficiency of the characters used. The oldest division of the genus was based upon the number of leaves in the bundles, and this must still be considered a supplementary character of considerable importance. In late years, however, it has been discovered that most valuable characters are to be found in the internal structure of the leaves, meaning, of course, the secondary or foliage leaves. The great diversity in the structure of these leaves is in marked contrast with the uniformity found in leaves of higher plants, and of itself is no mean argument in defense of the position of gymnosperms as the lowest of phanerogams.

\footnotetext{
${ }^{1}$ Read before the A. A. A. S., Buffalo meeting, 1886.

2Explanation of Figures.- - 1 . P. Strobus, 2 dorsal peripheral ducts, stomata on ventral faces, and single fibro-vascular bundle, $X 54 ; 2$. P. clausa, 2 parenchymatous ducts, stomata on all faces, and 2 fibro-vascular bundles, $X 54 ; 3$. $P$. Cubensis, internal duct, $X 54 ; 4 . P$. Arizonica, 3 cells of the bundle-sheath with thick outer walls, $X 250 ; 5$. P. monophylla, thinwalled bundle-sheath, $\mathrm{X} 250 ; 6$. P . aristata, strengthening cells next the epidermis, $X 250$; 7. $P$. flexilis, thin-walled layer (pitted) next the epidermis, $X 250 ; 8$. P. taberculata, thinwalled layer between epidermis and strengthening cells, $X 250$.
} 